This PDF is a selection from a published volume from the National Bureau of Economic Research

Volume Title: The Intended and Unintended Effects of U.S. Agricultural and Biotechnology Policies

Volume Author/Editor: Joshua S. Graff Zivin and Jeffrey M. Perloff, editors

Volume Publisher: University of Chicago Press

Volume ISBN: 0-226-98803-1; 978-0-226-98803-0 (cloth)

Volume URL: http://www.nber.org/books/perl10-1

Conference Date: March 4-5, 2010

Publication Date: February 2012

Chapter Title: The Politics and Economics of the U.S. Crop Insurance Program

Chapter Authors: Bruce A. Babcock

Chapter URL: http://www.nber.org/chapters/c12109

Chapter pages in book: (p. 83 - 112) 


\section{The Politics and Economics of the U.S. Crop Insurance Program}

Bruce A. Babcock

\subsection{Introduction}

Agricultural subsidies have been part of U.S. agriculture since the 1930s, when support for agriculture was a major part of the national economic stabilization effort of the New Deal. With the exception of the World War II period, the structure of subsidies from the 1930s until 1996 consisted of price supports that were defended by commodity storage and supply controls. Both were largely eliminated in 1996. The main form of support for agriculture today is a combination of $\$ 5$ billion per year of fixed direct payments that are decoupled from production, and crop insurance, which has turned into a $\$ 7$ billion program.

It could be argued that deadweight losses from the current system of subsidies are lower than the past combination of supply control and price supports if government revenue is raised efficiently and if the crop insurance program provides farmers with an efficient risk transfer mechanism that the private sector cannot provide. Glauber and Collins (2002), in their review of the history of the crop insurance program, note that private crop insurance markets have routinely failed in the past because of the systemic nature of crop losses. However, they also note that another explanation for the lack of a private crop insurance market may be a lack of demand. If the private sector cannot provide adequate crop insurance, then it is possible that government provision of this missing risk transfer market could improve welfare. But if private insurance markets do not exist because of a lack of demand, then government creation of a crop insurance industry likely leads to large welfare losses.

Bruce A. Babcock is professor of economics and director of the Center for Agricultural and Rural Development at Iowa State University. 
In this chapter, I first explore in some detail whether there is empirical evidence of unmet demand for crop insurance that could justify government creation of the market. I use two years of cross-section data to make this determination. The two years span a large change in the actuarial fairness crop insurance premiums that allows revelation of the farmer demand for actuarially fair insurance. Determination of whether crop insurance contracts that are offered to farmers are actuarially fair is not trivial because the rate-making methods used by the responsible government agency were not consistent with actuarial fairness. One contribution of this chapter is the construction of a data set that estimates the degree to which corn, soybean, and wheat farmers were offered insurance contracts that were overrated, underrated, and were actuarially fair.

The empirical section of the chapter finds support for the notion that a substantial number of farmers will increase the amount of actuarially fair insurance that they buy. Although this result accords well with standard expected utility theory, it runs counter to current crop insurance policy and much of the current literature that maintains that farmers need to be heavily subsidized before they will increase their purchase of insurance. One explanation for the large premium subsidies can be found by looking at interest groups who gain from large premium subsidies. A detailed examination of the interest groups who capture rents from the program provides insight into the political forces that have worked to defend and expand the program subsidies. The program serves as a case study that follows closely the predictions of Becker's (1983) theory of legislation as a reflection of economic payoffs from the application of pressure by affected interest groups.

The chapter begins with a general overview of the program. This overview is needed to understand how interest groups extract rents from the program. The construction of a unique data set is then detailed to show how expected producer returns for increased crop insurance coverage can be estimated. The demand for increased insurance coverage is estimated for the subset of the data that includes actuarially fair insurance contracts and for the entire sample. The chapter then moves to an exploration of competition within the crop insurance program and identifies which interest group, other than farmers, captures the lion's share of rents in the program. A brief examination of legislative history that corroborates who benefits from the program along with an assessment of current crop insurance policy that builds on the chapter's results concludes.

\subsection{Overview of the U.S. Crop Insurance Program}

Policy objectives of the U.S. crop insurance program can be found from the public statements of policymakers. Objectives include to help farmers manage financial risk and to eliminate the need for Congress to pass supplemental ad hoc disaster assistance programs. Congress dramatically restructured the crop insurance program in 2000 with the Agricultural Risk 
Protection Act (ARPA). The reform was justified by President Clinton in his statement upon signing the Agricultural Risk Protection Act (ARPA) of 2000: "I have heard many farmers say that the crop insurance program was simply not good value for them, providing too little coverage for too much money. My FY 2001 budget proposal and this bill directly address that problem by making higher insurance coverage more affordable, which should also mitigate the need for ad hoc crop loss disaster assistance such as we have seen for the last three years." And in 2006 testimony before the House Subcommittee on Agriculture, Rural Development, Food and Drug Administration, and Related Agencies, former U.S. Department of Agriculture (USDA) undersecretary J. B. Penn said, "One of the overarching goals of the crop insurance program has been the reduction or elimination of ad hoc disaster assistance."

By all accounts, Congress has seemingly succeeded in its objective to help farmers manage risk. Coverage is provided to more than 350 commodities in all fifty states and Puerto Rico. And more than 80 percent of eligible acres are now insured under the program. The Congressional Budget Office projects crop insurance outlays in excess of $\$ 7$ billion for the foreseeable future.

Table 3.1 provides summary program information since 2001 . The first column shows that insured acreage has increased substantially since 1998.

Table 3.1

National crop insurance data

\begin{tabular}{|c|c|c|c|c|c|c|}
\hline Year & $\begin{array}{c}\text { Insured } \\
\text { acreage }^{\mathrm{a}} \\
\text { (million acres) }\end{array}$ & $\begin{array}{l}\text { Total } \\
\text { premiums }^{\mathrm{a}} \\
\text { (\$ million) }\end{array}$ & $\begin{array}{c}\text { Total } \\
\text { indemnities }^{\mathrm{a}}\end{array}$ & $\begin{array}{l}\text { Premium } \\
\text { subsidies }^{\mathrm{a}} \\
\text { (\$ million) }\end{array}$ & $\begin{array}{l}\text { Administrative } \\
\text { and operating } \\
\text { subsidies }^{b}\end{array}$ & $\begin{array}{c}\text { Net } \\
\text { underwriting } \\
\text { gains }^{\mathrm{c}}\end{array}$ \\
\hline 1998 & 182 & 1,876 & 1,678 & 946 & 445 & 279 \\
\hline 1999 & 197 & 2,310 & 2,435 & 955 & 499 & 272 \\
\hline 2000 & 206 & 2,540 & 2,595 & 951 & 554 & 282 \\
\hline 2001 & 211 & 2,962 & 2,960 & 1,772 & 634 & 348 \\
\hline 2002 & 215 & 2,916 & 4,067 & 1,741 & 627 & -47 \\
\hline 2003 & 217 & 3,431 & 3,261 & 2,042 & 734 & 378 \\
\hline 2004 & 221 & 4,186 & 3,210 & 2,477 & 887 & 692 \\
\hline 2005 & 246 & 3,949 & 2,367 & 2,344 & 829 & 965 \\
\hline 2006 & 242 & 4,579 & 3,503 & 2,682 & 930 & 887 \\
\hline 2007 & 272 & 6,562 & 3,547 & 3,824 & 1,339 & 1,682 \\
\hline 2008 & 272 & 9,857 & 8,664 & 5,693 & 2,011 & 1,163 \\
\hline $2009^{d}$ & 264 & 8,948 & 5,164 & 5,425 & 1,619 & 2,146 \\
\hline
\end{tabular}

aTaken from Summary of Business reports of the Risk Management Agency of the U.S. Department of Agriculture.

bCalculated from exhibit 5, table 5.1 of Grant Thornton LLP and "Total premiums" in this table.

'Underwriting gains through 2008 taken from exhibit 1 in Grant Thornton LLP.

${ }^{\mathrm{d}}$ Current as of July 11, 2010. Administrative and operating subsidies estimated by multiplying 2009 estimated premium by 18.1 percent, reflecting the cut in administrative and operating subsidies reimbursement enacted in 2009. Underwriting gains in 2009 estimated from historical relationship between gross and net underwriting gains. 
Most of this increase came about because pasture land became eligible for insurance during this period. Total premium is the amount of premium that companies are credited with by the USDA's Risk Management Agency (RMA), which administers the program. The amount of premiums that farmers actually pay equals total premiums less premium subsidies. Both have grown tremendously over this period. Indemnities are the amount of insurance claims paid to farmers. Administrative and Operating (A\&O) costs are paid to crop insurance companies as cost compensation. Net underwriting gains are the amount of gross underwriting gains that companies keep after federal reinsurance gains and losses are calculated. Taxpayer costs equal subsidies plus net underwriting gains plus total indemnities paid to farmers minus farmer-paid premiums. Each of these is discussed in turn.

\subsubsection{Administrative and Operating Subsidies}

In 1980, Congress decided that delivery of the crop insurance program should be given to the private sector so that the program could be expanded as rapidly as possible. Companies had an incentive to expand sales because they were essentially paid a sales commission. For each dollar of premium they brought in, companies were given a percentage. That percentage, called $\mathrm{A} \& \mathrm{O}$, was reduced by 2.3 percentage points (from approximately 20.7 percent of premium) beginning in 2009.

\subsubsection{Net Underwriting Gains}

A gross underwriting gain occurs in the crop insurance program when premiums exceed indemnities. In these years, crop insurance companies get to keep a portion of the difference. The portion they keep is called the net underwriting gain. For example, in 2004, premiums exceeded claims by $\$ 979$ million. Companies were allowed to keep $\$ 848$ million of this difference. In years in which premiums are less than insurance claims, companies may have to pay a portion of the difference, an underwriting loss. In 2002, claims exceeded premiums by $\$ 1.15$ billion. Companies had to pay the government $\$ 52$ million of this amount.

The 2002 and 2004 examples nicely illustrate why, on average, crop insurance companies expect to generate underwriting gains. In years in which underwriting gains are positive, companies get to keep a larger proportion of the gain than they have to pay the government in years in which there are underwriting losses. The mechanism by which net gains and losses are determined is the Standard Reinsurance Agreement (SRA).

Companies generate net gains from the SRA in three ways. The first is by determining which of their customers are most likely to generate claims and then giving the premium from these customers and responsibility for any subsequent losses directly to the government. The average customer retained by a company, therefore, has a better risk profile than the average customer 
in the overall pool. Thus, average claims from the retained pool will be lower than the overall average, and the company will tend to make money.

However, the overall risk of loss from retained customers is still too large for companies to be willing to take on all losses. Hence, the SRA is designed to have the government take on a portion of company losses when claims exceed premiums in exchange for companies giving the government some of their gains when premiums exceed claims. In exchange for companies taking on some of the risk of the crop insurance program, the government is allowing companies to generate some gains. It is almost as if crop insurance companies are selling taxpayers an insurance policy. In years where crop losses are high, taxpayer losses are reduced because some of the losses are covered by the "policy." The "premium" that taxpayers pay for this policy are the underwriting gains that companies garner in years where crop losses are small. Whether taxpayers are getting a good deal by this bargain depends on the size of the premium paid in good years relative to the payments received in bad years.

Table 3.2 summarizes one set of conservative estimates of the potential gains and losses to private crop insurance companies from operation of the current SRA. These estimates are based on loss experience from 1993 to 2005 and likely understate the actual underwriting gains that companies currently expect to make. The table presents four equally likely scenarios regarding crop insurance claims. With $\$ 8$ billion in premiums, companies should expect to make $\$ 868$ million per year in net underwriting gains, which is simply the average net underwriting gain across the four scenarios. In exchange for paying companies this average annual amount, taxpayers reduce their loss exposure by $\$ 440$ million with a 25 percent probability. This simple example demonstrates that taxpayers would be much better off selfinsuring by having the federal government simply and directly take over risk rather than sharing the risk at such a high cost.

The third way that companies make money from the SRA is that gains and losses are calculated for each state separately. Given the asymmetry of net gains and losses, separate ceilings on losses for each state will result

Table 3.2

Potential gains and losses to crop insurance companies under the Standard Reinsurance Agreement

\begin{tabular}{lccc}
\hline Insurance claim loss scenario & $\begin{array}{c}\text { Loss ratio (indemnity } \\
\text { over premium) }\end{array}$ & $\begin{array}{c}\text { Ratio of gain to } \\
\text { total premium }\end{array}$ & $\begin{array}{c}\text { Total gain to companies } \\
\text { (US\$ million) }\end{array}$ \\
\hline Very low & 0.53 & 0.238 & 1,904 \\
Moderately low & 0.72 & 0.136 & 1,088 \\
Moderately high & 0.76 & 0.115 & 920 \\
Very high & 1.28 & -0.055 & -440 \\
Average & 0.82 & 0.108 & 868 \\
\hline
\end{tabular}

Source: Estimated by author. 
in lower overall losses that more than compensate the benefits of separate ceilings on gains.

\subsubsection{Producer Premium Subsidies}

The last taxpayer cost category is premium subsidy. Farmers must pay for crop insurance, but they pay only a portion of the amount needed to cover insured losses. Throughout the 1980s and 1990s, farmers were reluctant to buy enough crop insurance to satisfy Congress. So to get farmers to buy more insurance, ARPA dramatically decreased the portion that farmers must pay. Currently, farmers pay about 41 percent of the amount needed to cover insured losses. This large subsidy means that most farmers will get substantially more back from the program than they pay into it. As will be shown, the large increases in premium subsidies under ARPA also allows for estimation of producer demand for actuarially fair insurance contracts because before the change, most farmers needed to pay more than actuarially fair amounts for low deductible policies, and after the change, many farmers needed to pay less than actuarially fair amounts for increased coverage.

\subsection{Demand for Crop Insurance}

One justification for federal provision of the crop insurance program is the inability of the private sector to meet risk averse farmers' demands for insurance. The primary reason given for this inability is lack of poolability in insurance claims (Miranda and Glauber 1997). Indeed, crop risk bears many of the characteristics of an uninsurable risk. As noted by Miranda and Glauber, the coefficient of variation of loss ratios is much higher than most other forms of property and casualty insurance. One solution to this lack of poolability is to reinsure in capital markets with catastrophic bonds. In 2009 , in excess of $\$ 3.4$ billion of cat bonds were issued (Johansmeyer 2010), which implies that the total amount of at-risk capital now exceeds $\$ 12$ billion (GC Securities 2009). Whether the current crop insurance liability of $\$ 80$ billion could all be reinsured in capital markets is untested because the U.S. taxpayer currently provides reinsurance for the program. Thus, there is at least some possibility that, without public intervention, there could be underprovision of insurance in agriculture. However, a necessary condition for underprovision is an excess demand for insurance by farmers at the level of insurance that the private sector would offer.

The evidence for unmet demand seems weak. Goodwin (1993) showed that demand for insurance is driven primarily by increases in expected indemnities in excess of premiums. His analysis covered a period of quite low participation (1985 to 1990) when adverse selection was likely widespread. Goodwin (1993) estimated expected indemnities by a ten-year average ratio of indemnities received to premiums paid. Just, Calvin, and Quiggin (1999) modeled farmer participation in crop insurance by comparing 
farmers' expectations of indemnities with insurers' expectations of indemnities and found that asymmetric information was significant in explaining which farmers purchased crop insurance in 1988. They find that risk aversion played a minor role in explaining the incentive to buy insurance. Rather, the opportunity to obtain positive expected returns provides the primary motivation.

These two studies provide little evidence of unmet demand for actuarially fair insurance. However, both studies were conducted when crop insurance participation was quite low. For example, in 1988, only 24.5 percent of eligible acres were enrolled in the program (Food and Agricultural Policy Research Institute [FAPRI] 1999). Thus, it is not surprising that adverse selection was important in determining who participated in the program. More recently, however, participation has become much higher. In 1998 and 2002 (the two years studied here), participation increased to 67.9 percent and 80.2 percent of eligible acres, respectively. The importance of adverse selection in the participation decision should be much lower with such a large share of producers now participating in the program. The question that motivated the study by Just, Calvin, and Quiggin (1999) — whether the pursuit of higher expected returns or risk aversion is what drives crop insurance demand - is still key to determining whether producer welfare gains from provision of a missing risk transfer market can justify government provision of crop insurance.

Consider a risk-averse, expected-utility-maximizing farmer who grows a single crop. The farmer can choose to insure crop yield at any coverage level $\alpha$. The insurance contract is of the form $I=\max (\alpha \bar{y}-y, 0)$, where $I$ is the insurance indemnity, $\bar{y}$ equals expected yield, and $y$ is realized crop yield. Normalizing crop price to unity, and denoting the distribution of yield as $g(y), 0 \leq y \leq y \max$, and the insurance premium as $r(\alpha)$, expected utility for the producer with this insurance contract is

$$
E U=\int_{0}^{\alpha \bar{y}} U[\alpha \bar{y}-c-r(\alpha)] g(y) d y+\int_{\alpha \bar{y}}^{y \max } U[y-c-r(\alpha)] g(y) d y .
$$

If $r(\alpha)$ is actuarially fair, then $r(\alpha)=\int_{0}^{\alpha \bar{y}}(\alpha \bar{y}-y) g(y) d y$. Risk averters will demand full insurance if insurance is actuarially fair (Arrow 1974) or if premiums are subsidized at lower-than-actuarially fair levels. In either case, expected utility is increasing in $\alpha<y$ max $/ \bar{y}$. Risk averters will also demand full insurance even if insurance premiums are higher than actuarially fair levels if risk premiums are large enough. Risk neutral producers, however, buy insurance only if expected indemnities exceed premiums paid.

The U.S. crop insurance program limits $\alpha$ to a maximum of 0.85 , a minimum of 0.5 , and increments of 0.05 . Thus, if risk-averse farmers were offered actuarially fair yield insurance, then all would tend to buy the maximum amount of coverage with $\alpha=0.85$. This observation would indicate excess demand for insurance by risk-averse producers and evidence that 


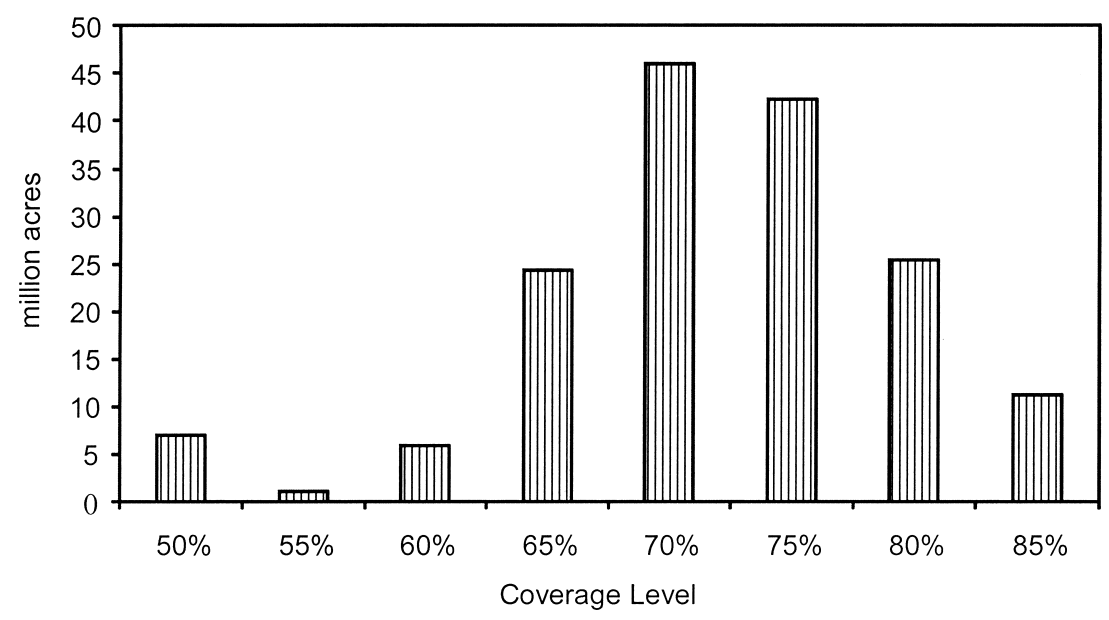

Fig. 3.1 Acres insured at different coverage levels for corn, soybean, and wheat producers in 2009

Source: Summary of Business reports from the Risk Management Agency (RMA) of the U.S. Department of Agriculture.

demand for crop insurance is sufficient to potentially justify government support for the market.

However, it is easily verified that farmers do not, in fact, all buy 85 percent coverage. Figure 3.1 shows that the 85 percent coverage level was actually one of the least popular coverage levels among corn, soybean, and wheat farmers in 2009.

The paucity of 85 percent policies in 2009 by itself is not sufficient evidence to conclude that there is no excess demand for crop insurance. An alternative explanation is that the incremental price that farmers must pay for 85 percent policies is higher than actuarially fair levels. Although USDA's RMA is supposed to set premium rates that are actuarially fair, the RMA places a surcharge on low-deductible policies in an effort to combat adverse selection. Loss experience data that RMA considered in the early 2000s convinced the RMA that farmers who were more likely to suffer crop losses tended to purchase low deductible policies. In addition, the percent premium subsidy declines as farmers move to higher coverage levels. Babcock and Hart (2005) demonstrated that many of the insurance contracts offered to farmers for 85 percent coverage decrease expected returns relative to 80 percent coverage.

The hypothesis to be tested here is whether expected utility is increasing in $\alpha$ when farmers are offered actuarially fair insurance. Evidence in support of this hypothesis would be a large preponderance of farmers moving to high coverage levels when offered increased coverage at an actuarially fair price. To test this hypothesis requires data that measure farmers' coverage-level purchase decisions that are matched up with an estimate of the incremental (to coverage level) actuarial fairness of the crop insurance contracts that 
are offered to farmers. It is not sufficient to look at participation decisions to answer this question because large premium subsidies make expected returns to participation positive for most farmers. However, wide variations in incremental actuarial fairness across crops, space, and time allows identification of farmer demand for actuarially fair insurance. Insurance data from corn, soybeans, and wheat in 1998 and 2002 are used to test the hypothesis. Because this time period had similar participation rates to current participation, the results from this analysis are more relevant for the current program than results that relied on pre-1995 data.

\subsubsection{Construction of a Data Set Measuring Variation in Actuarial Fairness of Low Deductible Policies}

Although the RMA has an objective of setting premiums at actuarially fair levels for all coverage, most of its efforts at doing so are concentrated on determining actuarially fair rates when $\alpha=0.65$. The RMA uses historical loss data as the basis for determining premiums for a crop in a county. To account for the different coverage levels that farmers purchase, the RMA recalculates historical losses as if all farmers purchased 65 percent policies. Babcock, Hart, and Hayes (2004) demonstrated that the RMA's method that was in place until 2003 for determining the incremental premium cost for crop insurance for non-65 percent policies did not lead to actuarially fair incremental premiums even if the 65 percent premium was actuarially fair. For high-risk crops and regions, the incremental cost was too high, leading to higher-than-actuarially-fair premiums. For the lowest-risk crops and regions, the incremental cost was too low. ${ }^{1}$

As shown in figures 3.2 and 3.3, there exists tremendous spatial variation in the riskiness of corn and soybean production. Risk here is measured by the average premium rate charged in a county for a 65 percent policy that protects against yield loss (Actual Production History [APH] insurance). This variation in riskiness combined with the Babcock, Hart, and Hayes (2004) result implies that there were large variations in the degree to which incremental crop insurance premiums were actuarially fair.

The premium rates illustrated in figures 3.2 and 3.3 express premium as a percent of liability. These rates vary across counties by a factor of more than seven with the lowest rates in the central Corn Belt and the highest rates in the Southeast. To measure the incremental farmer cost and expected indemnity of increasing $\alpha$, the costs and expected indemnities could be calculated

1. The RMA changed their rating methods not in response to the publication of the Babcock, Hart, and Hayes (2004) paper but rather to an external review of their rating methods in response to concerns by the crop insurance industry that the incremental cost of Revenue Assurance, which incorporated the Babcock, Hart, and Hayes rating methods, was too low. The external review concluded that the incremental cost of Revenue Assurance premium rates were correct. The RMA responded to this finding by making the incremental costs of Crop Revenue Coverage and Actual Production History correspond to those of Revenue Assurance. A note of disclosure: the author of this article was responsible for developing the rating methods for Revenue Assurance. 


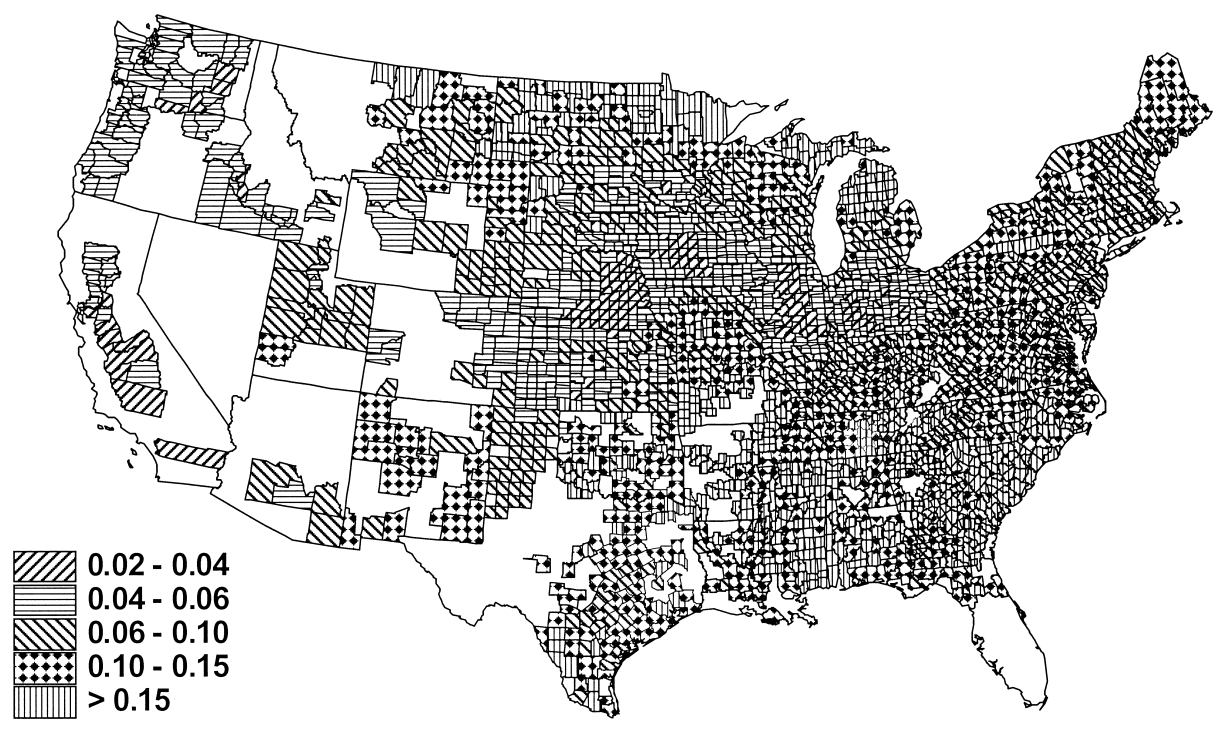

Fig. 3.2 Premium rates for 65 percent Actual Production History (APH) corn insurance for the 2002 crop year

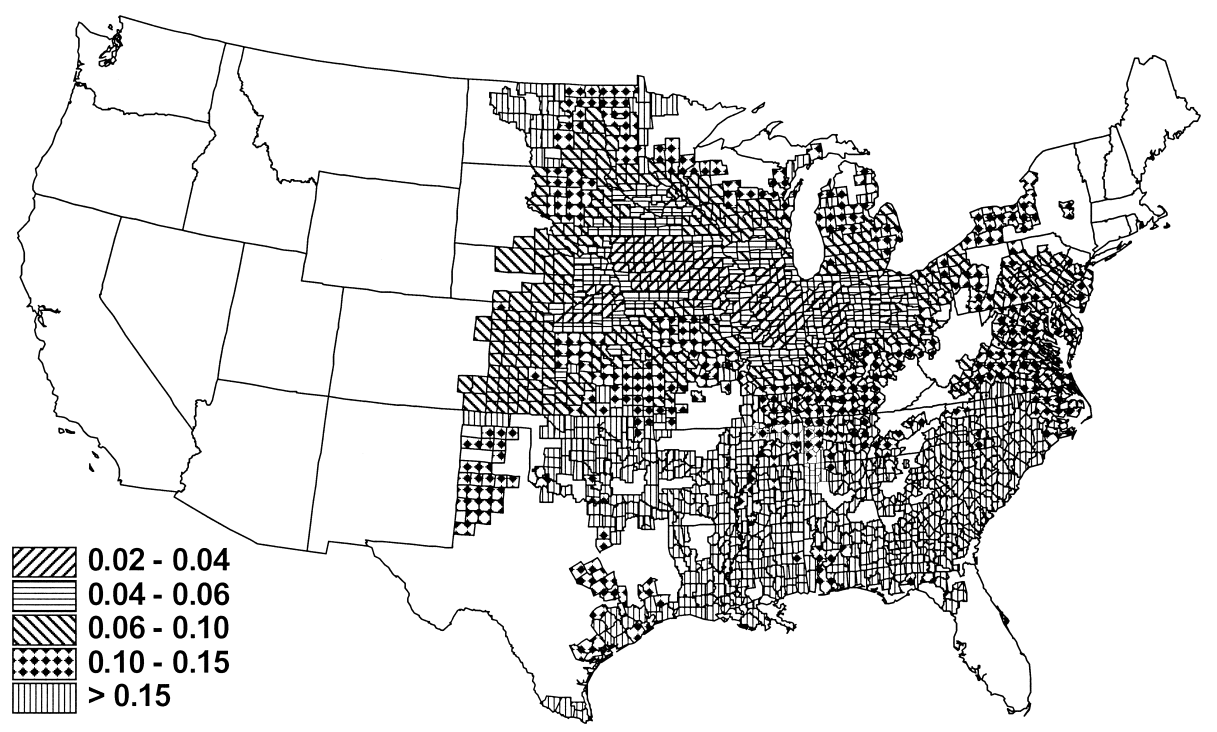

Fig. 3.3 Premium rates for 65 percent deductible Actual Production History (APH) soybean insurance for the 2002 crop year 
at all coverage levels. However, in the late 1990s, many farmers could not buy policies with $\alpha>0.75$. Thus, to allow data from 1998 to be combined with data from 2002, incremental expected returns of moving from $\alpha=0.65$ to $\alpha=0.75$ are calculated.

Output prices, expected yields, and production costs are independent of $\alpha$. Thus, the change in expected returns from increasing crop insurance coverage equals the change in expected indemnities $(I)$ minus the change in producer paid premiums (PP).

$$
\Delta \pi=\mathrm{E}\left(I_{75}\right)-\mathrm{E}\left(I_{65}\right)-\left(\mathrm{PP}_{75}-\mathrm{PP}_{65}\right)=\Delta I-\Delta \mathrm{PP},
$$

where the subscript denotes $\alpha$. If premiums are actuarially fair and unsubsidized, then $\Delta \pi=0$.

\section{Incremental Costs of Crop Insurance Coverage}

To estimate $\triangle \mathrm{PP}$ in equation (1) requires an accounting of the actual subsidies and premiums charged. The 2002 ARPA changed the subsidy structure but not the premium structure, so we need to estimate $\Delta \mathrm{PP}$ both before and after ARPA. It is straightforward to calculate $\Delta P P$. Denoting 65 percent and 75 percent premium rates (premium divided by liability) as rate65 and rate 75 , the premium subsidy rates at 65 percent and 75 percent as psub65 and psub75, and the insurance price as $p$, the change in the producer premium for the APH plan of insurance is

$$
\begin{aligned}
\Delta \mathrm{PP}= & (1-\mathrm{psub75}) \cdot \operatorname{rate} 75 \cdot p \cdot 0.75 \cdot \bar{y} \\
& -(1-\mathrm{psub65}) \cdot \operatorname{rate65} \cdot p \cdot 0.65 \cdot \bar{y} .
\end{aligned}
$$

Both before and after ARPA, 75 percent coverage premium rates (dollars of premium per dollar of liability) for the APH program for corn, soybeans, and wheat equal the 65 percent coverage premiums multiplied by the constant 1.538. Therefore,

$$
\begin{aligned}
\Delta \mathrm{PP}= & p \cdot \bar{y} \cdot \operatorname{rate} 65 \\
& \cdot[1.538 \cdot 0.75 \cdot(1-\mathrm{psub} 75)-0.65 \cdot(1-\mathrm{psub} 65)],
\end{aligned}
$$

which under pre-ARPA conditions equals approximately $0.5 \times p \times \bar{y} \times$ rate65. After ARPA, premium subsidy rates were increased from 41.7 percent to 59 percent for 65 percent coverage and from 23.5 percent to 55 percent for 75 percent coverage. Thus, $\triangle \mathrm{PP}$ after ARPA is approximately $0.25 \times$ $p \times \bar{y} \times$ rate65, which demonstrates that ARPA cut the incremental cost of moving to $\alpha=0.75$ in half for all U.S. corn, soybean, and wheat farmers.

\section{Incremental Expected Indemnities from Higher Coverage Levels}

If unsubsidized premium rates were set at actuarially fair levels for all $\alpha$, then the change in expected indemnities from moving to $\alpha=0.75$ would equal the change in unsubsidized premium: 


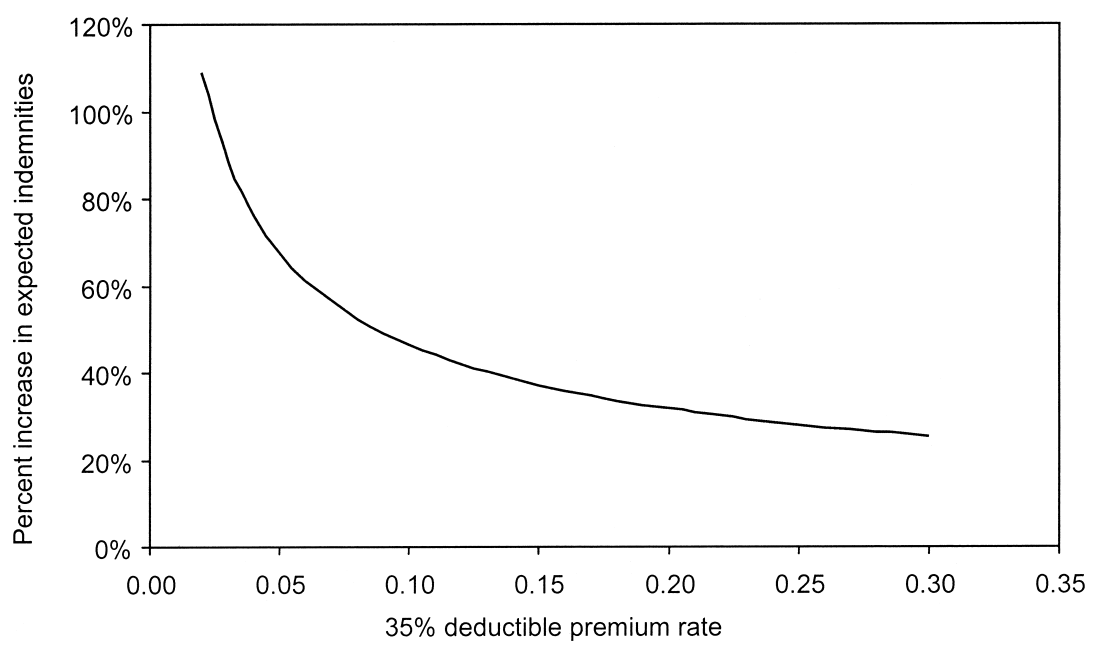

Fig. 3.4 Increase in expected indemnities from moving to 75 percent from 65 percent coverage

$$
\Delta I=p \cdot \bar{y} \cdot(0.75 \cdot \operatorname{rate} 75-0.65 \cdot \operatorname{rate} 65) .
$$

Babcock, Hart, and Hayes (2004) demonstrate that a negative relationship must exist between rate 65 and the ratio of rate 75 to rate 65 if both rates are to be actuarially fair. That is, in high-risk regions, the incremental rate increase as one moves to a 75 percent policy is much lower than the incremental increase in low-risk regions. But crop insurance rates for APH had, until 2003, a constant ratio of rate75 to rate65. Thus, the actual premiums charged cannot be used to estimate $\Delta I$ as in equation (4).

Figure 3.4 shows the relationship between $\Delta I$, expressed as a percent change, and alternative premium rates for $\alpha=0.65$. This relationship was estimated using Monte Carlo integration of yield draws from a beta distribution. The beta parameters were calibrated to generate draws that lead to average (across the yield draws) indemnities that equal each alternative premium rate on the horizontal axis. The beta distribution is regularly used to model yield distributions for crop insurance because of its flexibility. The relationship between the change in expected indemnities and the 65 percent premium rates ( 35 percent deductible rates) illustrated in figure 3.4 is robust across alternative functional forms for the yield distribution. Thus, if the 65 percent premium rate is actuarially fair, then applying the figure 3.4 relationship will lead to an estimate of $\Delta I$ given any 65 percent premium rate.

What we want to determine is whether farmers who are offered incrementally actuarially fair insurance increase their insurance coverage. The data that will be used include only those farmers who have already decided to purchase crop insurance. The purchase decision means that farmers have 
already decided that crop insurance generates net benefits, either in the form of higher expected returns or reductions in risk.

With $\alpha=0.65$, farmers received a 41.7 percent premium subsidy in 1998 and a 59 percent subsidy in 2002 . These large premium subsidies imply that nearly all farmers are offered a base level of coverage that generates positive expected returns. Thus, it is not surprising that even risk-neutral farmers would find it beneficial to participate in the program. But the figure 3.4 negative relationship combined with the RMA's rule of a constant ratio between premiums rates at 75 percent and 65 percent means that there was a wide variation across crops and regions in expected returns from increasing $\alpha$.

The change in premium and expected indemnities measures the degree to which insurance is actuarially fair at the margin. I measure demand for incremental insurance as the ratio of acres insured at $\alpha>0.65$ to acres insured at $\alpha=0.65$. The unit of observation is the county, as in Goodwin (1993). A unit of observation is a county-crop combination. Demand for more insurance is calculated in 1998 and 2002 for each county where corn, soybeans, and wheat were insured.

The number of insured acres at each coverage level for all insurance products is available from the RMA's Summary of Business reports. Data for 1998 and 2002 were used for a number of reasons. The ARPA was passed in June of 2000. Its subsidy provisions went into effect immediately, but farmers had already made their decisions about which coverage level to purchase, so there would be little or no impact from ARPA in 2000. Crop year 2001 data could have been used but it takes time for farmers and the industry to learn about significant changes in policy. Insurance agents must be notified and trained, quoting software must be adjusted, and then farmers must be made aware of the impacts of change. Hence, the 2002 data should more fully reflect awareness of the ARPA policy changes and subsequent changes in coverage levels.

We could also extend the analysis to 2003 and 2004 crop year data, but beginning with the 2003 crop year, the RMA began to implement a new set of premium rates and surcharges at higher coverage levels. The RMA phased these changes in so it would be difficult to accurately calculate the actual insurance offers being made to farmers in these years.

A special 25 percent premium reduction program was implemented late in 1999, reducing producer paid premiums by an additional 25 percent. Undoubtedly, some proportion of agents and their farmer clients were aware of this program, but many were not. Thus, assuming that all farmers made their 1999 coverage-level decisions with full information would be incorrect. A premium reduction program was also in place in 1998, but it was announced after farmers had made their crop insurance decisions. Thus, we can assume that 1998 decisions reflect their prior knowledge about premium and subsidy rates.

In 1998, 71 percent of corn, soybean, and wheat acres were insured with 
APH. In 2002, only 34 percent of acres were insured with APH. To account for the rapid movement of producers away from APH insurance to revenue insurance products over this time period, the analysis is extended to estimating the actuarial fairness of the offer price for increased Crop Revenue Coverage (CRC) from 65 percent to 75 percent. First, an explanation of how expected returns to incremental APH coverage is explained.

I estimate the actuarially fair cost of moving to 75 percent coverage from 65 percent coverage as being equal to the product of the average 65 percent premium rate offered to producers in a county who chose to buy at least 65 percent coverage and one plus the percentage increase in expected indemnities shown in figure 3.4. The procedure used to measure the average 65 percent premium rate for those producers who purchased at least 65 percent coverage is best explained with an example.

Table 3.3 presents 2002 corn data for Cass County, Illinois. At each coverage level, the average premium rate is calculated by dividing total premium by total liability. The average rate at each coverage level is then converted to the corresponding average 65 percent rate by dividing it by the appropriate rate relativity factor used by RMA. These rate relativity factors are 1.0 for 65 percent coverage, 1.215 for 70 percent coverage, 1.538 for 75 percent coverage, 1.954 for 80 percent coverage, and 2.462 for 85 percent coverage. The result of this multiplication is reported in the last column of table 3.3. The average 65 percent rate is then calculated by taking the acreage-weighted average of the results in the last column. In this example, the average rate is 0.0591 .

Given this estimate of the average rate, we can estimate the average expected gain from moving to 75 percent coverage. Using the beta distribution that generated the relationship in figure 3.4, the actuarially fair 75 percent premium rate is 0.0825 . Then using the preceding expressions for $\Delta I$ and $\Delta \mathrm{PP}$ after ARPA, we have $\Delta I=0.02346 \times p \times \bar{y}$ and $\Delta \mathrm{PP}=0.014927 \times$ $p \times \bar{y}$. Thus, the change in expected profits is $0.008533 \times p \times \bar{y}$. This change in expected profits is normalized by dividing through by the estimate of $\Delta I$. The result then represents the change in expected profits as a percent change.

Table 3.3 Data for Cass County used to calculate average 65 percent premium rates

\begin{tabular}{lcccccc}
\hline $\begin{array}{l}\text { Coverage } \\
\text { level (percent) }\end{array}$ & $\begin{array}{c}\text { Insurance } \\
\text { plan }\end{array}$ & $\begin{array}{c}\text { Insured acres } \\
\text { (acres) }\end{array}$ & $\begin{array}{c}\text { Total } \\
\text { liability }(\$)\end{array}$ & $\begin{array}{c}\text { Total } \\
\text { premium }(\$)\end{array}$ & $\begin{array}{c}\text { Average } \\
\text { rate }\end{array}$ & $\begin{array}{c}\text { Average } \\
65 \% \text { rate }\end{array}$ \\
\hline 65 & APH & 2,446 & 456,555 & 28,563 & 0.0626 & 0.0626 \\
70 & APH & 113 & 21,138 & 1,269 & 0.0600 & 0.0494 \\
75 & APH & 341 & 75,912 & 4,590 & 0.0605 & 0.0393 \\
80 & APH & 36 & 8,525 & 651 & 0.0764 & 0.0391 \\
85 & APH & 0 & 0 & 0 & NA & NA \\
\hline
\end{tabular}

Source: Summary of Business reports from USDA RMA, http://www3.rma.usda.gov/apps/sob/. Note: $\mathrm{APH}=$ actual production history; $\mathrm{NA}=$ not available. 
In this example, the result is 0.36 , which means that the change in expected profit amounts to 36 percent of the change in expected indemnity. In this case, the percent subsidy is positive. If the change in expected profits is negative, then farmers would be forced to pay more than actuarially fair amounts for lower deductible policies. The preceding procedure was implemented for every county in 1998 and 2002 in which corn, soybeans, or wheat was insured under the APH plan of insurance.

It is instructive to calculate the percent subsidy for Cass County before ARPA. Assuming that the average 65 percent premium rate in 1998 was 0.0591 , the change in expected profit is $-0.006296 \times p \times \bar{y}$, which translates to a -27 percent subsidy. That is, Cass County farmers were being asked to pay 27 percent more than the actuarially fair incremental cost for 75 percent coverage in 1998. This switch from a 27 percent tax to a 36 percent subsidy is illustrative of the magnitude of the change in actuarial fairness of the choices facing U.S. farmers after passage of ARPA.

Calculating the change in expected profits from higher coverage levels with CRC would seem more difficult than with APH because the CRC rating structure contains three separate components (yield risk, revenue risk, and price risk), and a portion of the change in expected indemnities is due to price variability. However, examination of the relationship between 65 percent APH premium rates and CRC premium rates at the 65 percent, 75 percent, and 85 percent coverage levels reveals an exact linear relationship. Thus, the 65 percent APH premium rate can be used to estimate the change in producer premium for $\mathrm{CRC}$ as coverage increases from 65 percent to 75 percent. What remains is how to calculate the change in expected indemnities for CRC.

Because CRC premiums used the same constant rate relativities that were used to determine APH premium rates, they cannot be used to calculate expected indemnities. What is needed is an independent measure of the change in expected indemnities that is based on a revenue distribution, much like the beta yield distribution was to generate figure 3.4. The rating equations from a competing revenue insurance product, Revenue Assurance (RA), that had lower market penetration than CRC during this period can be used to estimate the change in expected indemnities. The coverage provided by RA with the harvest price option is nearly identical to CRC. The RA rating equations are based on Monte Carlo integration of revenue draws as discussed in Babcock and Hennessy (1996). ${ }^{2}$

Before moving to a discussion of results, it is useful to pause and consider the accuracy of my measure of actuarial fairness. First, as stated in the preceding, my measure is accurate insofar as the RMA's premium rate for 65 percent coverage is actuarially fair. Coble et al. (2010) recommend that the RMA continue to use its loss-cost method of rate making, which

2. The RA rating equations are available upon request from the author. 
suggests that they conclude there is no better alternative. Loss experience in the period 2000 to 2008 has led some to conclude that premium rates are higher than actuarially fair in Corn Belt states and lower than actuarially fair in Great Plains states (Woodard et al. 2008). If true, then my estimate of what is an actuarially fair offer for marginal coverage in the Corn Belt would actually be a subsidized offer. And for Great Plains farmers, my estimate of an actuarially fair offer would actually be an offer that is priced too high. Evidence of this bias would be a greater take-up of actuarially fair offers in Corn Belt counties relative to Great Plains counties.

The next source of possible error in measurement arises from my using the county as my observational unit. Farmers in a county face different 65 percent coverage rates because they are judged to present different amounts of risk to the insurance pool. I implicitly assume that there is a single representative farmer in a county that faces an incremental price of higher coverage. If my estimate of actuarial fairness is accurate for the mean farmer in a county and farmers in a county are actually distributed around that mean farmer, then about half of farmers were offered more subsidized margin premiums than I measure, and half were offered less-subsidized marginal premiums. There are two factors that mitigate against this being a source of inaccuracy. First, the variability in risk across counties is much larger than the variability in risk within a county. Second, I account for intracounty distributions by defining actuarially fair premiums as being within 10 percentage points of what my measure takes to be as being absolutely fair.

As with all empirical studies, sample selection bias warrants discussion. My sample consists of all farmers who chose to insure their corn, soybeans, and wheat in 1998 and 2002. Between 20 percent and 30 percent of acreage was not insured in this time period. Nonparticipating farmers felt that they had more cost-effective means of risk management than crop insurance, which could imply that they were being offered insurance on too unfavorable terms. Thus, my analysis is only relevant for those farmers who chose to participate. That the increase in premium subsidies in 2000 brought increased participation suggests that participating farmers in 2002 were, on average, of lower risk than farmers who participated in 1998. To the extent that the average 65 percent premium offered to these farmers was actuarially fair, then this difference in level of risk is accounted for.

Finally, some explanation for why nobody else has conducted this type of analysis is needed. I am not the first to estimate the actuarial fairness of insurance offers to farmers. For example, Just, Calvin, and Quiggin (1999) estimated differences between farmers' perceptions of actuarial fairness and the actual premiums they were being charged. They used these differences to predict which farmers chose to buy insurance. One explanation for the differences in actuarial fairness was a lack of rating data caused by low participation. Nobody, to my knowledge, has focused on putting together 
a data set to calculate the actuarial fairness of the offer that farmers faced for higher coverage levels. Perhaps this is not too surprising because most crop insurance demand studies have focused on the participation decision, rather than on the demand for higher coverage. My focus on marginal coverage arose because in 2002, I was in the unique position of having to defend the large discrepancies between how fast RA premium rates increased as farmers chose to buy more coverage relative to how fast premium rates for competing products increased. Farmers in high-risk counties were moving rapidly to RA from CRC because RA marginal premiums were sometimes less than half what they would have had to pay for CRC. Because the crop insurance industry obtained far fewer premium dollars because of this movement, they forced the RMA to review whether RA premium rates were too low. The work that went into demonstrating to the RMA and the industry that RA marginal rates were accurate is what provided me with the background to put together this data set.

\subsection{Results}

Table 3.4 provides summary statistics of the entire data set. As shown, the number of counties where farmers purchased APH and CRC insurance is higher in 2002 than 1998 for each crop. The average percent subsidy in 1998 ranged from a low of -83 percent for $\mathrm{CRC}$ wheat to a high of -60 percent for $\mathrm{CRC}$ corn. This meant that, on average, farmers were forced to pay more

Table 3.4

Data summary by crop, year, and insurance type

\begin{tabular}{|c|c|c|c|c|}
\hline & \multicolumn{2}{|c|}{1998} & \multicolumn{2}{|c|}{2002} \\
\hline & APH & $\mathrm{CRC}$ & APH & CRC \\
\hline \multicolumn{5}{|l|}{ Corn } \\
\hline No. of observations & 1,878 & 1,026 & 2,022 & 1,730 \\
\hline Average subsidy ${ }^{a}$ & $-65 \%$ & $-60 \%$ & $17 \%$ & $-1 \%$ \\
\hline Acre ratio ${ }^{b}$ & 0.09 & 0.18 & 0.39 & 0.62 \\
\hline \multicolumn{5}{|l|}{ Soybeans } \\
\hline No. of observations & 1,520 & 947 & 1,707 & 1,384 \\
\hline Average subsidy & $-62 \%$ & $-83 \%$ & $18 \%$ & $-11 \%$ \\
\hline Acre ratio & 0.10 & 0.21 & 0.50 & 0.67 \\
\hline \multicolumn{5}{|l|}{ Wheat } \\
\hline No. of observations & 1,621 & 806 & 1,664 & 1,403 \\
\hline Average subsidy & $-72 \%$ & $-82 \%$ & $16 \%$ & $-7 \%$ \\
\hline Acre ratio & 0.16 & 0.16 & 0.37 & 0.60 \\
\hline
\end{tabular}

Note: $\mathrm{APH}=$ actual production history; $\mathrm{CRC}=$ crop revenue coverage.

${ }^{a}$ Ratio of change in expected returns from insuring at 75 percent coverage level to change in expected indemnities from moving to 75 percent coverage from 65 percent coverage.

${ }^{b}$ Ratio of acres insured at greater than 65 percent coverage to acres insured at 65 percent coverage or above. 
than actuarially fair amounts for higher levels of yield insurance in 1998. In contrast, in 2002, farmers, on average, were offered higher levels of insurance at close-to-actuarially fair premiums.

Histograms that show the distribution of the degree to which buying additional coverage was subsidized in 1998 and 2002 across counties are presented in figures 3.5 and 3.6 for APH and CRC, respectively. For counties with more than one crop, the average percent subsidy across crops is used. As shown, the change in subsidy structure that took place in 2000 dramatically moved these distributions to the right. This move coincides with the large increase in the percent of acres insured above the 65 percent coverage level as shown in table 3.4. These histograms also show that there are many more counties that were offered actuarially fair increases in insurance in 2002, thus allowing for a better estimation of how many farmers will increase coverage when offered an actuarially fair premium.

A straightforward method for estimating the demand for actuarially fair insurance is to use only those observations where the offer is actuarially fair. Table 3.5 presents results taking counties that fall in the range of -10 percent to +10 percent percent subsidy as being actuarially fair. Overall, almost 50 percent of acreage is insured at higher coverage levels by farmers when offered actuarially fair premiums for the higher coverage. This

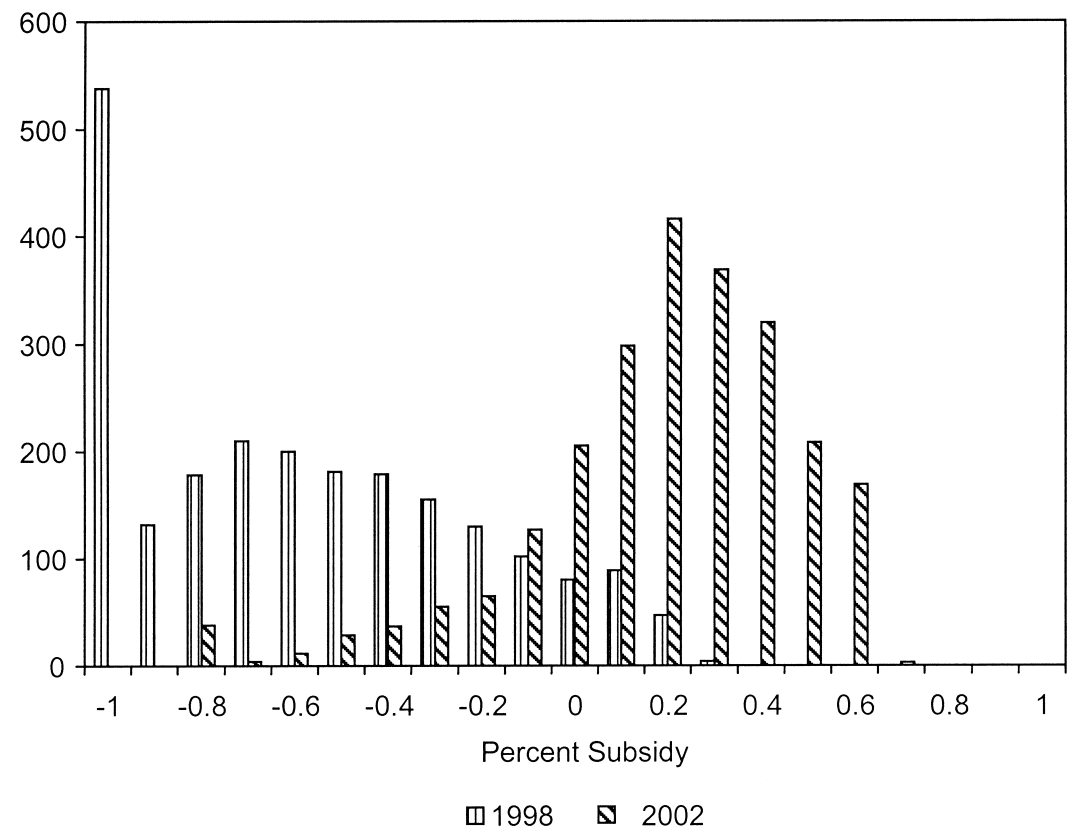

Fig. 3.5 Distribution of percent subsidy for Actual Production History (APH) across counties in 1998 and 2002 


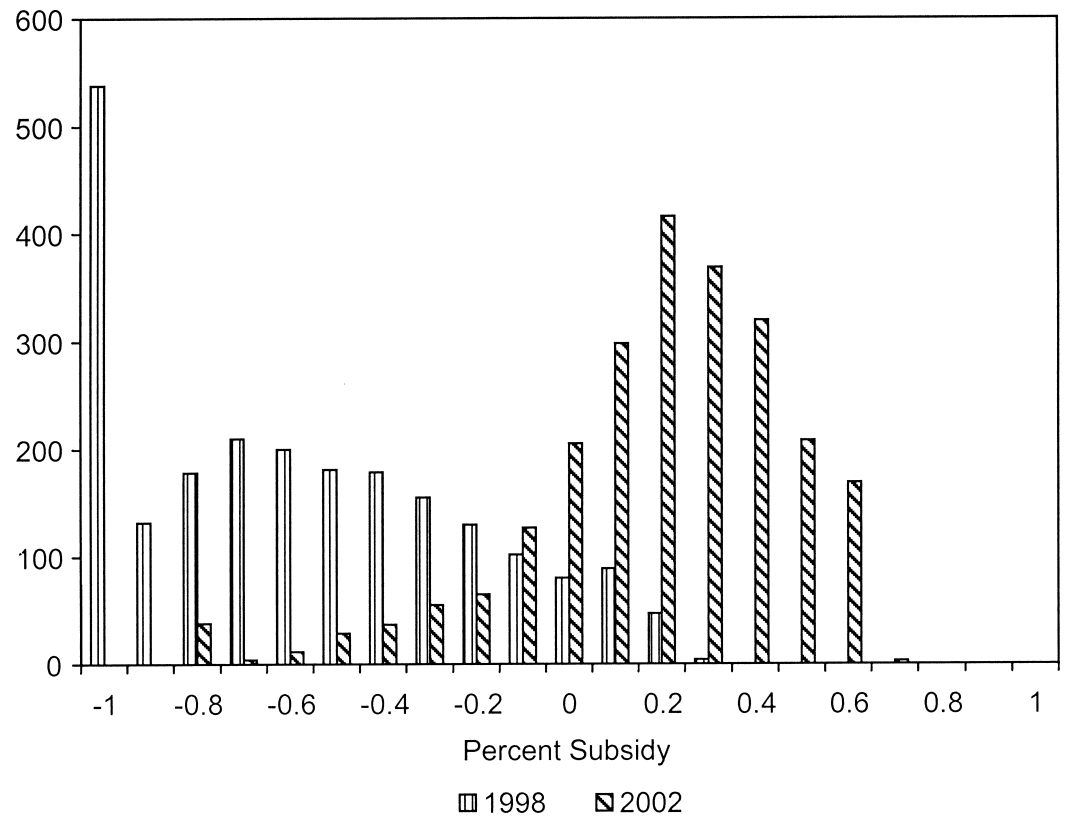

Fig. 3.6 Distribution of percent subsidy for Crop Revenue Coverage (CRC) across counties in 1998 and 2002 Share of acres insured at higher coverage under actuarially fair insurance

\begin{tabular}{lcc}
\hline & Acre ratio $^{\text {a }}$ & No. of observations \\
\hline Entire sample & 0.47 & 3,425 \\
1998 & 0.27 & 562 \\
2002 & 0.51 & 2,863 \\
APH & 0.30 & 1,565 \\
CRC & 0.62 & 1,860 \\
APH-1998 & 0.26 & 528 \\
APH-2002 & 0.32 & 1,039 \\
CRC-1998 & 0.40 & 36 \\
CRC-2002 & 0.62 & 1,824 \\
\hline
\end{tabular}

Note: $\mathrm{APH}=$ actual production history; $\mathrm{CRC}=$ crop revenue coverage.

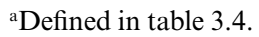

proportion seems to have increased in 2002 relative to 1998, but a large part of this apparent increase is caused by the increase in acreage insured under CRC. Farmers are about twice as likely to take the offer of actuarially fair insurance when they buy CRC than when they buy APH. Given the low number of observations of available in 1998, and the small increase from 1998 to 2002 in the proportion of acreage insured at higher coverage levels 
for $\mathrm{APH}$, it is not apparent that the demand for actuarially fair insurance increased in 2002.

To determine whether the point estimates of differences in demand for actuarially fair insurance are statistically different can be accomplished by regressing the proportion of observed acres insured at higher-than- 65 percent coverage level on indicator variables that control for plan of insurance, year, and crop. Because this proportion cannot exceed 1.0 or fall below 0.0 , a two-limit Tobit regression procedure is appropriate to use. Two sets of regression results are reported in table 3.6. The first column of results use only 2002 data to indicate if the difference between the demand for actuarially fair insurance by producers who buy CRC is statistically different than for producers who buy APH. As shown, the results support this difference. In addition, the demand for actuarially fair insurance for soybeans is statistically higher than the demand from farmers who buy insurance for their corn and wheat crops. This sample was defined by the percent subsidy. Within the range of plus or minus 10 percent in percent subsidy, the dollar per acre value of the subsidy could still affect the demand for insurance. Thus, the dollar value of the subsidy was included in the regressions. As one would expect, increases in the dollar value of subsidy increases the demand for insurance.

The second set of results is used to test if the demand for actuarially fair insurance increased in 2002. This test is best run using only APH observations because the first regression results indicate that the demand is higher for those who buy CRC, and this demand is primarily exhibited in 2002.

Table 3.6 Regression results for observations where percent subsidy is between $+I-10$ percent

\begin{tabular}{lcc}
\hline Sample & 2002 only & APH only \\
\hline Constant & $0.713^{* * *}$ & $0.241^{* * *}$ \\
& $(0.0157)$ & $(0.0217)$ \\
APH dummy & $-0.377^{* * *}$ & \\
& $(0.0164)$ & \\
Corn dummy & $-0.107^{* * *}$ & $-7.84 \mathrm{E}-03$ \\
& $(0.0190)$ & $(0.0232)$ \\
Wheat dummy & $-0.099^{* * *}$ & $8.79 \mathrm{E}-03$ \\
& $(0.0200)$ & $(0.0255)$ \\
Dollar subsidy & $0.112^{* * *}$ & $0.123^{* * *}$ \\
& $(0.0264)$ & $(0.0381)$ \\
2002 dummy & & 0.026 \\
& & $(0.0208)$ \\
Sigma & $0.404^{* * *}$ & $0.375^{* * *}$ \\
& $(0.0067)$ & $(0.0084)$ \\
\hline
\end{tabular}

Notes: Standard errors are shown in parentheses. APH = actual production history. ***Denotes an asymptotic $t$-statistic that is significant at the 1 percent level. 
The hypothesis that demand did not change between 1998 and 2002 cannot be rejected.

These results indicate that the demand for actuarially fair insurance is most important to those producers who buy CRC. Furthermore, more than half of U.S. corn, wheat, and soybean acreage that was able to be insured at higher insurance levels at actuarially fair rates was insured at the higher rates for producers who chose CRC. This insurance product is designed not only to reduce the risk of revenue falling short of a targeted amount, but it is also designed to offset the added financial risk of forward contracts. Many farmers hesitate to forward contract because if they do not produce enough to deliver against the contract, and if market prices have risen above the forward contract price, then they must enter the market to buy expensive grain to fulfill their contract. Thus, the risk management benefits of CRC should be expected to be higher. The results indicate that this is so.

The final regression is to estimate the response of farmers' decisions about buying additional coverage as the percent subsidy increases. Table 3.7 provides the regression results for CRC only. Following Greene (1990, 738), predicted values from a two-limit Tobit model were calculated and reported in figure 3.7. For all three crops, the expected proportion of acres that would be insured at greater than the 65 percent coverage is above 50 percent. That the predicted value from the regression crosses the zero-subsidy point above 50 percent implies decreasing amounts of acreage being insured at higher coverage levels as subsidies increase.

As Babcock and Hart (2005) demonstrate, most farmers are now offered higher revenue insurance coverage (up to 80 percent) at producer premiums that generate positive expected returns. The results shown in figure 3.7 indicate that many farmers will buy higher levels of revenue insurance even if it was offered to them at actuarially fair levels. Given that farmers have shown that they will buy significant amounts of actuarially fair insurance, it is somewhat of a puzzle why premium subsidies for incremental crop insur-

Table 3.7 Regression results for all crop revenue coverage observations

\begin{tabular}{lc}
\hline Sample & Crop revenue coverage only \\
\hline Constant & $0.734^{* * *}$ \\
& $(0.0174)$ \\
Percent subsidy & $0.854^{* * *}$ \\
& $(0.168)$ \\
Corn dummy & $-0.152^{* * *}$ \\
& $(0.023)$ \\
Wheat dummy & $-0.094^{* * *}$ \\
& $(0.024)$ \\
Sigma & $0.385^{* * *}$ \\
& $(0.0077)$ \\
\hline
\end{tabular}

***Denotes an asymptotic $t$-statistic that is significant at the 1 percent level. 


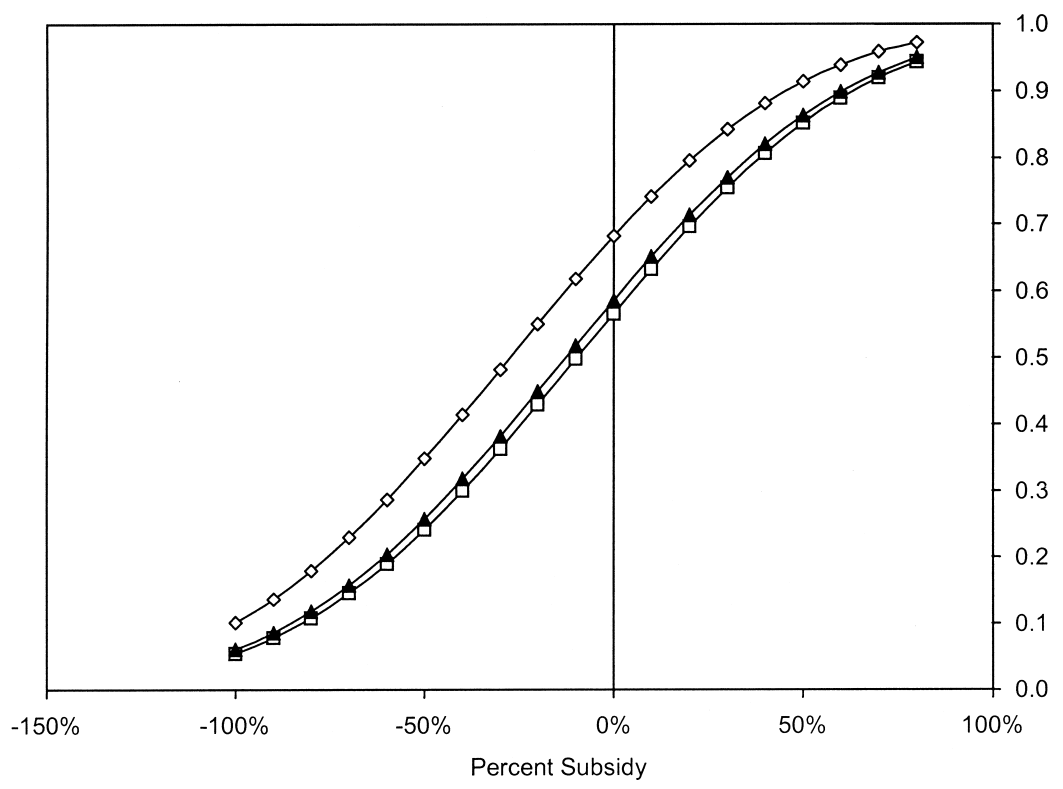

Fig. 3.7 Expected response of increased coverage to increased incremental subsidies

ance are so large. The results of this chapter suggest that a fixed amount of subsidy per acre to entice an adequate number of farmers to enter the program, and then a contract schedule of actuarially fair premiums would result in a large number of farmers buying a significant amount of insurance. One answer to this puzzle is that, when it passed ARPA in 2000, Congress was not aware that farmers were being forced to pay higher-than-actuarially fair incremental rates: all that was observed was that most farmers purchased the 65 percent coverage level. In response, Congress decided to increase premium subsidies to induce farmers to buy higher coverage levels. In this effort to increase premium subsidies, Congress was urged along by those interest groups who benefit from farmers buying high levels of insurance.

Stigler (1971) explains why government regulations often seem to chiefly benefit those who are regulated by the regulators being captured by the industry that they are regulating. And there is ample evidence that the crop insurance industry has a large amount of influence on the RMA. But Becker's (1983) theory of interest group influence over the political process is perhaps a better starting point for an explanation because the House and Senate Agricultural Committees have taken an unusually direct role in dictating how the crop insurance program is run.

Becker (1983) argues that the outcome of the legislative process reflects the pressures brought to bear by interest groups. The influence of powerful interest groups is only limited by increasing deadweight losses from their 


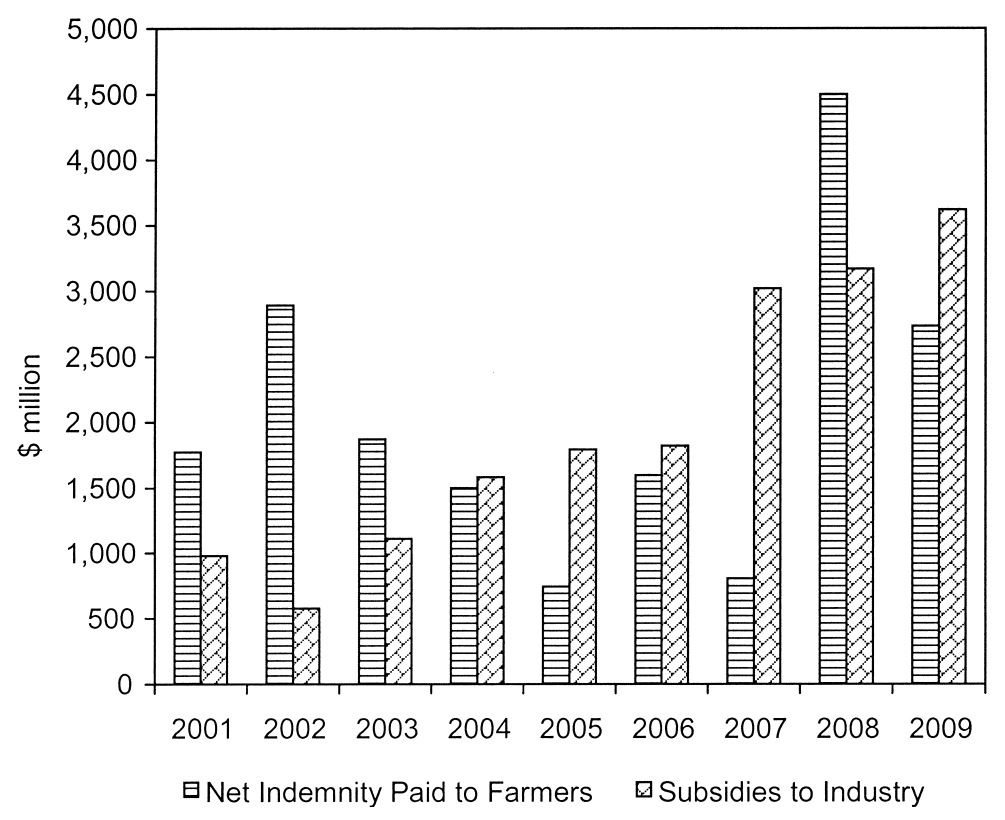

Fig. 3.8 Revenue from the crop insurance program

favored policies and by increased pressure from less-favored groups whose interests are increasingly adversely affected by policies that are adopted. Figure 3.8 shows the magnitude of the annual payments (calculated from table 3.1) made to the two beneficiaries of taxpayer support for crop insurance: farmers and the crop insurance industry. The next section explains competition in the crop insurance program to explain who in the industry actually benefits from the industry subsidies shown in figure 3.8.

\subsection{Crop Insurance Competition}

In this section, a descriptive model of competition in the public/private partnership that characterizes the crop insurance industry is developed. Data are used to validate the main prediction of the model that crop insurance agents are the residual claimants of rents that accrue to the industry.

There are six main interest groups in the crop insurance industry: taxpayers, Congress, government regulators, farmers, crop insurance agents, and crop insurance companies. Taxpayer subsidies created and provide continual support to the industry. Congress reacts to political pressure by passing laws that regulate and subsidize the industry. Regulators implement those laws. Farmers buy crop insurance from a crop insurance agent. Crop insurance agents decide which crop insurance company will receive each 
farmer's business. Agents make money by earning commission on each policy that they sell. The variable cost of selling policies is much less than the commission on most policies, so the more policies they sell, the more money agents make. Thus, agents have an incentive to compete with other agents for a farmer's business. Crop insurance companies make money from underwriting gains and from $\mathrm{A} \& \mathrm{O}$ reimbursements. The noncommission variable costs are much lower than $A \& O$ and expected underwriting gains in almost all states. These variable expenses include loss adjustment costs and labor. Thus, crop insurance companies make more money the more policies that they can obtain. This creates an incentive for companies to compete for agents' books of business. Agents, companies, and farmers have an incentive to lobby Congress to pass laws that work to their favor. As always, because the aggregate cost of the crop insurance program is spread among all taxpayers, opposition to the program by taxpayer groups is unfocused and relatively ineffective.

There exist three sources of competition in this descriptive model. The first is the competition between groups that lobby the House and Senate Agricultural Committees for part of the baseline agricultural budget. This competition pits the crop insurance industry against advocates for more farmer subsidies and advocates for greater spending on nutrition spending. For example, in 2007, the crop insurance industry argued against the reforms of commodity subsidies advocated by the National Corn Growers Association because the reforms would have transferred a large portion of the risk from the crop insurance program directly to taxpayers. More recently, a Des Moines Register (January 17, 2010) article about proposed cuts to crop insurance reported that "One of the industry's leading allies in Congress, Sen. Charles Grassley, R-Ia., said he believes the administration wants to use the $\$ 4$ billion in savings it would get from the cuts to increase spending for child nutrition programs, including school lunches." The outcome of this first competition is the aggregate amount of support that the industry receives from taxpayers.

The second source of competition is the competition between agents for farmers' insurance business. This competition cannot include price competition because of laws passed by Congress at the behest of agents. For example, the chief lobbying arm of crop insurance agents, the Independent Insurance Agents \& Brokers of America, sought a ban on a program that allowed crop insurance companies to reduce farmer-paid premiums by passing on a portion of agent commissions to farmers. Congress delivered a final ban on this type of price competition in the 2008 Farm Bill.

Because there is no possibility of price competition, agents must compete in terms of service. The types of service that can be offered include educating farmers about the types of insurance coverage offered, lowering the farmer cost of filling out required forms, and keeping farmers informed of any new information that may prove useful. All of these services are of second-order 
importance to farmers because either they are one-time benefits or because they do not directly increase farmers' profits. By default, a farmer's business remains with an agent year after year. So unless an agent convinces a farmer to switch agents, no switch will take place.

To a farmer, the benefit of switching must be greater than the cost of switching. The cost of switching includes a bit of paperwork, any social costs involved in moving business from one local neighbor or business person to another who may not be local, and the cost of searching for an agent that can provide superior service. Because there are positive switching costs and only indirect benefits, the incentive for most farmers to switch is not very large, although exact measurement of the incentive would be difficult. Consequently, the payoff from agent investments designed to induce farmers to switch will not be high. In equilibrium, each agent invests an optimal amount to keep their business and to perhaps attract new business, and each farmer has found the agent where the benefits of further switching are outweighed by the costs. Entry costs for new agents, involving the successful passing of a test on crop insurance are nominally low. But the real entry costs are actually quite high because new entrants will find it difficult to build up their book of business by inducing an adequate number of farmers to switch. Thus, each agent has essentially a captive book of business. ${ }^{3}$

Crop insurance companies use price to compete for agents' books of business. The price of an agent's business is the agent commission. Because most agents act independently of companies, they are free to sell their book to the highest bidder. There are approximately fifteen companies bidding for business. The maximum bid that a company will likely make is the difference between the expected revenue that an agent's book of business will bring in minus all noncommission variable costs. With sufficient competition, commission rates will exactly equal this difference. Thus, price competition between companies along with regulatory barriers that limit competition in premium rates make agents the residual claimant in the crop insurance industry. Evidence for agents being the residual claimant is that agent commissions vary dramatically across states. High commissions are paid where companies expect to make large underwriting gains; low commissions are paid in states with low or negative underwriting gains. The other possible residual claimant would be the owners of crop insurance companies, the management and staff of crop insurance companies, or loss adjusters. There may be a limited number of specialized crop insurance actuaries who are efficient at managing the risk profile of crop insurance companies and who, therefore, may capture increased rents. But there is no reason to think that

3. An indicator of the degree to which an agent has a captive book of business is the market value of the book. If the cost of switching were low and the benefits were high, then the market value of an agent's book of business would be low. But anecdotal evidence suggests that the market value of an agents' crop insurance book of business is multiples of the annual profit that can be generated from the book. 
the salaries paid to nonspecialized staff or executives should be above market rates of compensation. The Grant Thornton (2009) study on returns to the owners of crop insurance companies shows that the companies are actually making less than the return they have obtained from other lines of property and casualty insurance. The same Grant Thornton study provides convincing evidence that it is the crop insurance agents that are the residual claimant.

Figure 3.9 breaks shows how per-unit crop insurance costs have changed since 2001. Agent commissions are calculated by dividing total commission paid by the number of crop insurance policies. Other costs include crop insurance company salaries, computers, travel, and overhead. These costs are also expressed on a per-policy basis. Loss-adjustment costs are calculated by dividing total loss-adjustment costs by the number of units on which a loss was paid. The average annual growth in other costs is 5.61 percent. The average annual cost in loss adjustment costs is 6.1 percent per year. The Bureau of Labor Statistics reports that the average annual increase in civilian compensation over this time period was 3.4 percent. This suggests that some rents have accrued to claims adjusters and to staff of the crop insurance companies. But the growth and magnitude of compensation paid

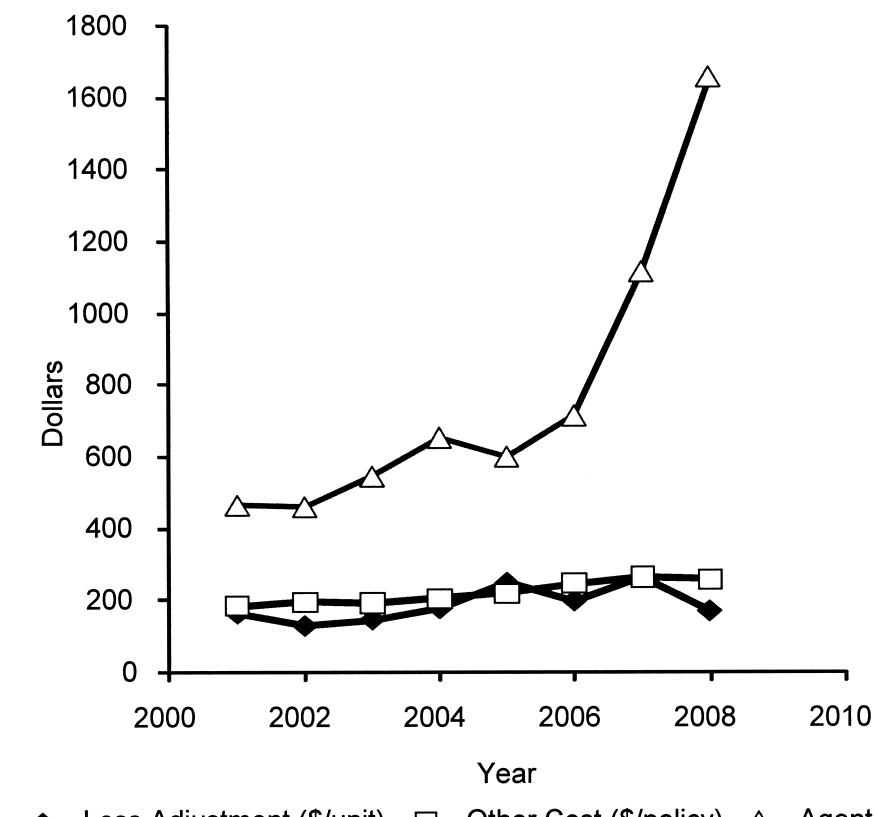

$\sim$ Loss Adjustment (\$/unit) $\square \square$ Other Cost (\$/policy) $\longrightarrow$ Agent Cost (\$/policy)

Fig. 3.9 Breakdown of crop insurance program costs

Source: Calculated from Grant Thornton reports prepared for the National Crop Insurance Services. 


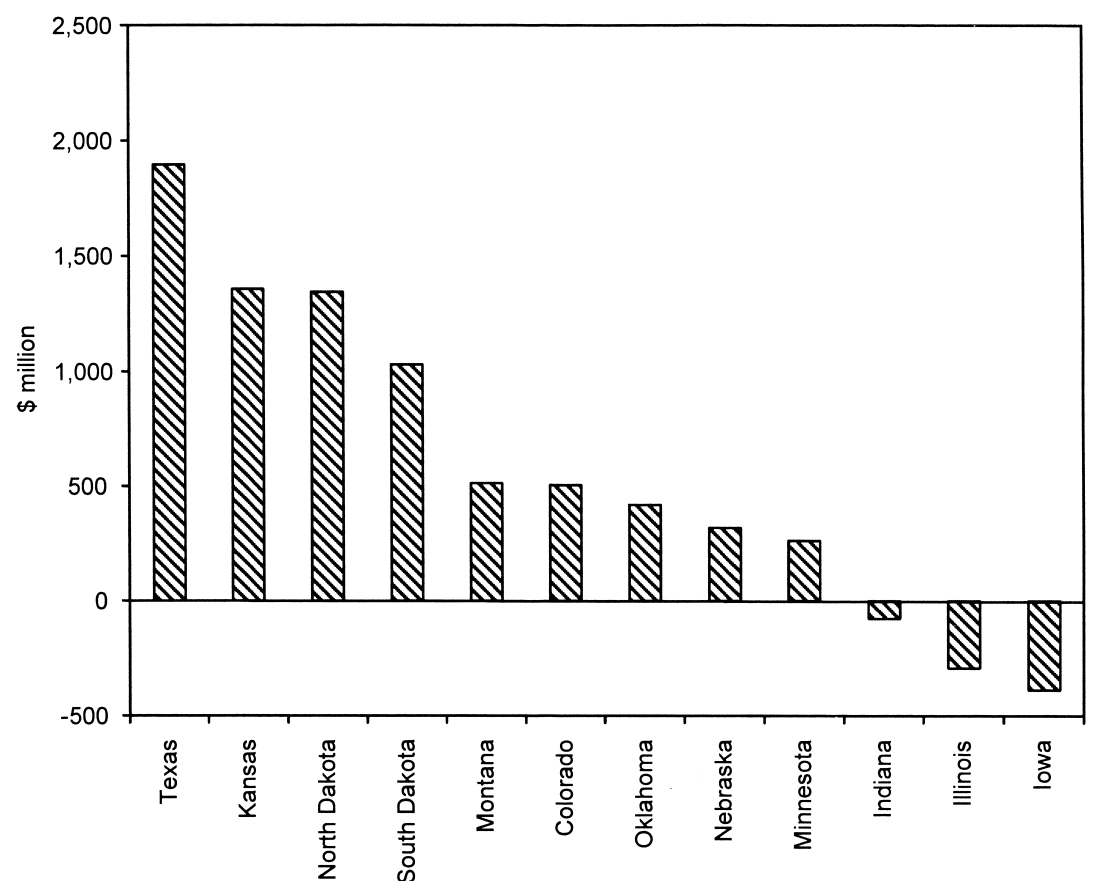

Fig. 3.10 Net indemnities received by farmers: 2000 to 2007

Source: Calculated by author from Summary of Business reports from the Risk Management Agency (RMA) of the U.S. Department of Agriculture.

to agents is convincing evidence that agents are the primary beneficiary of increased government support to the crop insurance program, as would be predicted if companies bid for agents' captive books of business.

Agents are not the only group that receives rents from the crop insurance program. As shown in table 3.1, farmers have garnered about $\$ 18$ billion more in payments than they have paid in premiums since 2001. However, not all regions of the United States have benefited equally from the program. Figure 3.10 shows that the Great Plains states have benefited by a much greater amount from the crop insurance program than have the Corn Belt states. This difference in benefits means that there is a natural alliance between crop insurance companies and members of Congress who represent areas outside of the Corn Belt. ${ }^{4}$

4. Evidence for of this alliance is contained in a press released from the National Corn Growers Association, quoted in a farm policy blog (http://www.farmpolicy.com/?p=520): "The National Corn Growers Association (NCGA) is pleased the Senate Agriculture Committee included a revenue option in the 2007 farm bill, but is disappointed by the committee's action to strip a key component of the optional revenue-based countercyclical program, the integration with federal crop insurance. It is a missed opportunity to provide a better risk management 
The outcome of this type of pressure group politics is a crop insurance program that operates for the benefit of crop insurance agents and that has generated positive expected returns for farmers in the Great Plains. The results of this study, combined with the figure 3.10 results, indicate that Corn Belt farmers have received more in risk management benefits that they have received in expected returns.

Becker's (1983) theory of competition between pressure groups shows that a limiting factor on the benefits bestowed on more powerful groups is that opposition to these benefits increases by losing groups the more that is given to winners. An implication of this part of his theory is that politicians will work to neutralize opposition by giving them benefits that do not come at the expense of the favored powerful group. In this case, in the new Farm Bill that was passed in 2008, Corn Belt farmers were given a new subsidy program called ACRE (Average Crop Revenue Election), which is a farm program that is not integrated with crop insurance. Thus, Corn Belt farmers obtained a new subsidy program, and Great Plains farmers and crop insurance agents were able to keep the crop insurance program.

\subsection{Conclusions}

The crop insurance program has grown so dramatically over the last ten years because private interests supported expansion of the program and Congress accommodated these private interests under the guise of expanding farmers' ability to manage production and price risk. But taxpayer costs of the program - along with the associated transfers to private industrygrew so large that some small steps were taken in 2010 to rein in costs. ${ }^{5}$ The policy question going forward is whether reform of the program could cut costs further while still meeting farmers' demands for efficient risk transfer tools, thereby increasing program efficiency. The results from this study provide insight into these questions.

The demand for crop insurance is motivated by both expected returns and risk reduction. This study presents estimates of demand for crop insurance that isolate the demand for risk reduction from the demand for expected returns by construction of a data set from which the farmer response to

tool in the new farm bill," said NCGA President Ron Litterer. An amendment accepted by the committee on a voice vote stripped the crop insurance integration from the revenue package. Corn growers support an optional revenue program starting in 2010. The ACR [Average Crop Revenue] plan initially put forward by Agriculture Committee Chairman Tom Harkin (D-Iowa) would have allowed farmers to insure part of their farm revenues directly through the government, costing private crop insurance companies an estimated $\$ 2.2$ billion over five years, according to the Congressional Budget Office. Along with an outcry from the industry, Harkin's plan ran into objections from Western senators who feared that insurance costs would rise as corn growers in the rainy Midwest shifted to the government plan.

5. Caps were placed on agent commission rates and overall $\mathrm{A} \& \mathrm{O}$ reimbursements with an objective of reducing government costs by about $\$ 600$ million per year. 
actuarially fair contract offers can be estimated. Results indicate that a large number of producers find that the risk reductions offered by revenue insurance generate significant value, suggesting that some public support for crop insurance may be useful if private provision of crop insurance is infeasible because of a lack of reinsurance markets.

These results also indicate that large premium subsidies are not needed to induce farmers to buy higher amounts of insurance because a significant proportion of farmers would buy actuarially fair insurance. However, significant adverse selection problems would arise if premium subsidies were withdrawn because it is difficult to offer insurance contracts that are individually actuarially fair. One method that would limit adverse selection problems would be to give farmers a lump-sum payment if they participate at some minimum coverage level in the program and then offer them the opportunity to buy more insurance at unsubsidized premium rates. Adverse selection would then be limited to the purchase of incremental coverage rather than to the entire insurance pool. Such a reform could reduce program costs substantially.

The larger question of whether the private sector could meet the crop insurance demands of farmers is difficult to answer because the private sector has been crowded out of the market for crop insurance. Total federal crop insurance liability in 2010 exceeded $\$ 78$ billion, with a significant portion of this risk located in the Corn Belt states of Iowa, Illinois, Indiana, Minnesota, Nebraska, and Missouri. This liability is small relative to hurricane liability, but recent difficulties in the market for insurance coverage against hurricane losses suggests that there is no assurance that private reinsurers would step in to facilitate private provision of the type of crop insurance that is currently being provided. ${ }^{6}$

\section{References}

Arrow, Kenneth. 1974. Essays in the Theory of Risk Bearing. New York: NorthHolland.

Babcock, B. A., and C. E. Hart. 2005. "ARPA Subsidies, Unit Choice, and Reform of the U.S. Crop Insurance Program.” Briefing Paper no. 05-BP 45. Ames, IA: Center for Agricultural and Rural Development, Iowa State University, February.

Babcock, B. A., C. E. Hart, and D. J. Hayes. 2004. "Actuarial Fairness of Crop Insurance Rates with Constant Rate Relativities." American Journal of Agricultural Economics 86:563-75.

Babcock, B. A., and D. Hennessy. 1996. "Input Demand under Yield and Revenue Insurance." American Journal of Agricultural Economics 78:416-27.

6. According to a recent (February 23, 2011) report in the Wall Street Journal, 25 percent of the Florida market for property insurance amounted to $\$ 451$ billion, with a 1 percent chance that losses from a hurricane could exceed \$20 billion. 
Becker, Gary S. 1983. "A Theory of Competition among Pressure Groups for Political Influence." Quarterly Journal of Economics 98 (3): 371-400.

Coble, K. H., T. O. Knight, B. K. Goodwin, M. F. Miller, and R. Rejesus. 2010. "A Comprehensive Review of the RMA APH and COMBO Rating Methodology Draft Final Report." Washington, DC: Risk Management Agency, U.S. Department of Agriculture. http://www.rma.usda.gov/pubs/index.html\#actuarial.

Food and Agricultural Policy Research Institute (FAPRI). 1999. Rainbow Book. A Summary of the November 1999 FAPRI Baseline. Columbia, MO: University of Missouri.

GC Securities. 2009. "Cat Bonds Persevere in Tumultuous Market." GC Capital Ideas, February 4. http://www.gccapitalideas.com/2009/02/04/cat-bonds-persevere -in-tumultuous-market/.

Glauber, J. W., and K. J. Collins. 2002. "Crop Insurance, Disaster Assistance, and the Role of the Federal Government in Providing Catastrophic Risk Protection." Agricultural Finance Review 62:81-101.

Goodwin, B. K. 1993. "An Empirical Analysis of the Demand for Multiple Peril Crop Insurance.” American Journal of Agricultural Economics 75:423-34.

Grant Thornton. 2009. "Federal Crop Insurance Program: Profitability and Effectiveness Analysis, 2009 Update." Prepared on behalf of the National Crop Insurance Services, Inc. Chicago: Grant Thornton LLP. www.ag-risk.org/NCIS PUBS/SpecRPTS/GrantThornton/Grant_Thornton_Report-2009_FINAL.pdf.

Greene, W. H. 1990. Econometric Analysis. New York: Macmillian.

Johansmeyer, T. 2010. "Catastrophe Bond Market Hits Target, Records Possible in 2010.” Blogging Stocks, January 4. http://www.bloggingstocks.com/2010/01/04/ catastrophe-bond-market-hits-target-records-possible-in-2010/.

Just, R. E., L. Calvin, and J. Quiggin. 1999. "Adverse Selection in Crop Insurance: Actuarial and Asymmetric Information Incentives." American Journal of Agricultural Economics 81:834-49.

Miranda, M. J., and J. Glauber. 1997. "Systemic Risk, Reinsurance, and the Failure of Crop Insurance Markets." American Journal of Agricultural Economics 79:205-15.

Risk Management Agency (RMA). Various years. "Summary of Business Report" www.rma.usda.gov/FTP/Reports/Summary_of_Business/sumbtxt.zip.

Stigler, G. 1971. "The Theory of Economic Regulation." Bell Journal of Economics and Management Science 2 (1): 3-18.

Woodard, J. D., G. D. Schnitkey, B. J. Sherrick, N. Lozano-Gracia, and L. Anselin. 2008. "A Spatial Econometric Analysis of Loss Experience in the U.S. Crop Insurance Program." Working Paper, University of Illinois. 